\title{
Ochrona zdrowia jako element polityki publicznej
}

7 drowie to jedno $\mathrm{z}$ podstawowych dóbr cenionych w polskim społe" czeństwie. Na zachowanie dobrego zdrowia jako jedną z najważniejszych wartości codziennego życia wskazuje niemal trzy piąte badanych (59\%). Wyżej cenione jest jedynie szczęście rodzinne (76\% wskazań) ${ }^{1}$. Jednakże deklarowany system wartościowania nie zawsze znajduje potwierdzenie w codziennych zachowaniach. „Mimo, iż istnieje dość silne społeczne przekonanie o tym, że dbanie o własne zdrowie nie jest dla Polaków bardzo ważne, paradoksalnie zdecydowana większość badanych (80\%) zalicza się do osób, które troszczą się o stan swego zdrowia. W porównaniu z rokiem 1993 ich odsetek zwiększył się aż o 22 punkty. Jednak tylko $17 \%$, czyli o 3 punkty więcej niż czternaście lat temu, stanowią ci, którzy nie mają wątpliwości co do swojego zaangażowania na rzecz prozdrowotnego stylu życia. Do braku troski o swoje zdrowie przyznaje się niespełna co piąty badany (19\%), a więc o połowę mniej niż w 1993 roku"2.

Postęp w dziedzinie medycyny okazuje się być ważnym, ale nie jedynym czynnikiem wpływającym na kondycję zdrowotną jednostek. Nie bez znaczenia dla dbałości o stan zdrowia pozostaje postęp cywilizacyjny. Z jednej strony znacząco poprawiły się warunki bytowania, ale równocześnie pojawiły się nowe zagrożenia, wynikające m.in. ze stylu życia, tak w odniesieniu do aktywności fizycznej, jak i higieny żywienia. Kobiety częściej korzystają z badań profilaktycznych względem mężczyzn. Pewne zachowania w ostatnich latach stały się konsekwencją dobrze prowadzonych kampanii profilaktycznych i informacyjnych, np., badania mammograficzne, a także wysokiego stopnia zaangażowania władz ogólnokrajowych i regionalnych.

Dotychczas kategoria pojęcia zdrowia nie została skonstatowana w jednej bezwzględnie obowiązującej definicji. Czynniki socjologiczne,

1 Zdrowie i zdrowy styl życia w Polsce, Warszawa 2007, BS/138/2007, s. 1.
2 Ibidem, s. 10 . 
antropologiczne nakazują analizowanie zdrowia, jako kategorii szczególnie cenionej przez społeczeństwo. W konsekwencji fakt, iż postrzegamy zdrowie, jako coś cennego, o co szczególnie dbamy zabiegamy pozwala na dokonanie analizy w ujęciu wartości ,zdrowia” i wartości „zdrowie”. Pierwsza jest postrzegana jako wartość sama w sobie, druga zaś odwołuje się do:

- „wartości odczuwanej - uznawanej przez jednostkę za rzeczywiście cenną, atrakcyjną, pożądaną, generującą podstawy emocjonalne i wyzwalającą działania (np. profilaktyczne, lecznicze): zależnej od stanu fizjologicznego organizmu (np., uczucie głodu) i stopnia zinternalizowania wpływów społecznych;

- wartości uznawanej - przekonanie jednostki, że zdrowie powinno być cenione, ponieważ postrzegane jest jako cenne w środowisku społecznym; przekonanie to w mniejszym stopniu jest oparte na emocjach, zawiera element powinności i często pozostaje w sferze deklaracji, ale jest trwalsze, bardziej ustabilizowane niż wartości odczuwane"3.

Zdrowie może być pojmowane jako kapitał przypisany człowiekowi, wynikający z braku choroby lub stanu chorobowego ${ }^{4}$, czy „stan żywego organizmu, w którym wszystkie funkcje (fizyczne i psychiczne) przebiegają prawidłowo", . Podkreślić należy, iż stan zdrowia nie jest identyfikowany tylko ze stanem ciała, ale coraz większą uwagę zwracamy na sferę psychologiczną. Słusznie podkreśla M. Kacprzak, że „,[...] nie tylko brak choroby czy niedomagań, ale i dobre samopoczucie oraz taki stopień przystosowania się biologicznego i społecznego, jaki jest osiagalny dla danej jednostki w najkorzystniejszych warunkach"“. Zgodzić się należy zatem z przyjętą przez Światową Organizację Zdrowia (WHO) definicją, że ,zdrowie jest pełnym dobrostanem fizycznym, psychicznym i społecznym, a nie wyłącznie brakiem choroby czy ułomności”7

3 Teoretyczne podstawy edukacji zdrowotnej. Stan i oczekiwania, red. B. Woynarowska, M. Kapica, Warszawa 2001, s. 38.

4 Termin choroba odzwierciedla niedyspozycje organizmu ludzkiego w danym czasie, zaś stan chorobowy ma wymiar długofalowy wynikający z przewlekłości choroby lub nagromadzenia chorób.

5 Słownik Języka Polskiego, pod red. W. Doroszewskiego, Warszawa 1986, S. 925 .

6 C. Korczak, J. Leowski, Problemy higieny i ochrony zdrowia, Warszawa 1977, s. 6 .

7 Konstytucja Światowej Organizacji Zdrowia porozumienie zawarte przez Rządy reprezentowane na Międzynarodowej Konferencji Zdrowia i Protokół do- 
W przyjętych stanowiskach zwrócono uwagę na dwa aspekty: elementy strukturalne oraz poziom funkcjonowania zapewniający ogólne poczucie dobrostanu, czyli integracji, sprawności, równowagi, braku napięć, lęków poczucie celu i sensu życia ${ }^{8}$. Funkcjonalny wymiar „odsyła do współczesnej myśli ekologicznej, ponieważ zdrowie określane jest jako dobre przystosowanie się do środowiska oraz zdolność do udziału w skutecznej interakcji ze światem materialnym i społecznym"9. Wpływ na kondycję zdrowotną mają warunki, w jakich człowiek funkcjonuje. Przywołać w tym miejscu należy koncepcję Marc'a Lalonde'a, który stwierdził, że cztery kryteria warunkują zdrowie człowieka;

- około 50\% jest konsekwencją stylu życia;

- około 20\% wynika ze środowiska fizycznego i społecznego życia, pracy, nauki;

- około 20\% uwarunkowana jest czynnikami genetycznymi;

- $10 \%$ to skuteczne działanie służby zdrowia ${ }^{10}$.

„Rzeczywistość zdrowotna postrzegana jest jako ciąg czynników i okoliczności powstających w obliczu zmieniających się realiów wzajemnie na siebie oddziałujących jednostka-otoczenie i otoczenie-jednostka wpływających na szerszy kontekst jego postrzegania - socjalizacyjnego czy społecznego" "11 zob. tabela 1.

tyczący Międzynarodowego Urzędu Higieny Publicznej, podpisane w Nowym Jorku dnia 22 lipca 1946 r., teks polski opublikowany w Dz. U. 1948.61.

${ }^{8}$ C. Korczak, J. Leowski, Problemy..., op. cit., s. 7.

9 Koncepcja Hipokratesa z Kos o dysfrakcji, czyli zaburzeniu równowagi (krazja), czterech płynów powoduje chorobę u człowieka. Por. Historia, ibidem 1988, s. 15. Por. J. Porn, Health and adaptedness, „Theoretical Medicine” 1993, nr 14, s. 295-303; E. Erde, Philosophical considerations regarding defining 'health', 'disease', etc, and their Bering on medical practice, „Ethics in science \& Medicine” 1979, nr 6, s. 31-48.

${ }_{10}$ M. LaLonde 1 maja 1974 roku przedstawił kanadyjskiemu parlamentowi raport pn. Nowa perspektywa dla zdrowia Kanadyjczyków (A New Perspective on the Health of Canadians - A Working Document), w którym po raz pierwszy zwrócono uwagę na warunki społeczne i dotyczące ekosystemu, jako czynniki warunkujące zdrowie człowieka. Por. Teoretyczne podstawy edukacji zdrowotnej. Stan i oczekiwania, red. B. Woynarowska, M. Kapica, Warszawa 2001.

${ }_{11}$ M. Kowalski, A. Gaweł, Zdrowie - wartość - edukacja, Kraków 2006, s. 67. 
Czynniki warunkujące zdrowie

Środowisko społeczne (rodzina, szkoła, grupy rówieśnicze itd.)

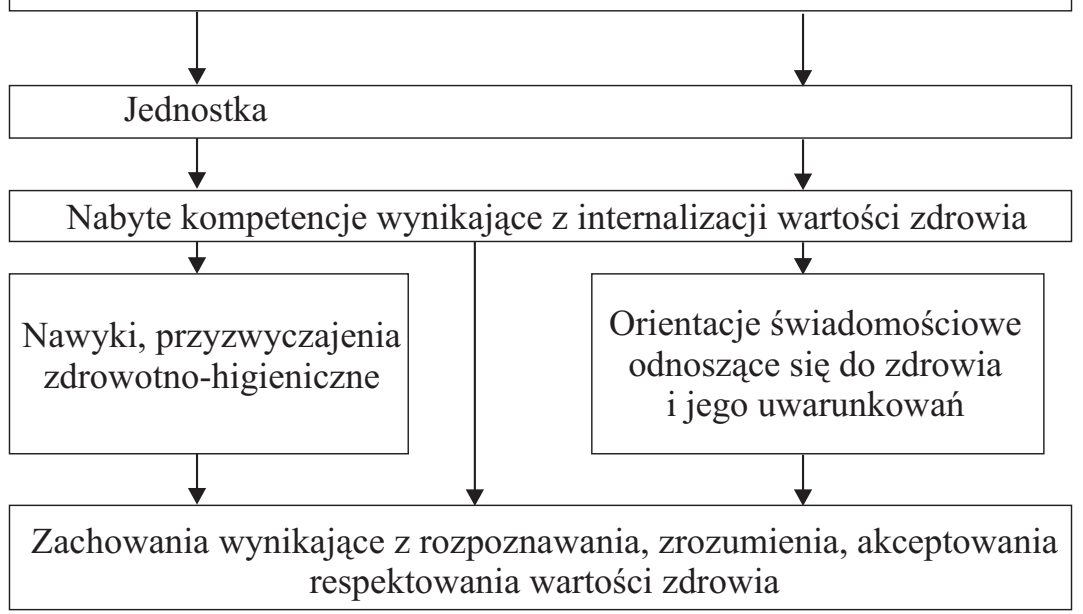

Źródło: M. Kowalski, A. Gaweł, Zdrowie - wartość - edukacja, s. 67.

XX wiek kierując się dewizą, że zdrowie jest nie tylko dane, ale i zadane, podkreślił znaczenie zdrowia nie tylko w sensie ideologicznym, uznano, że zdrowie ,,[... nie jest traktowane jako wartość autoteliczna, ale służebna" ${ }^{\prime 2}$. W podejmowanych działaniach na rzecz ochrony zdrowia decydującą pozycję zajmuje nie jednostka, lecz społeczeństwo, stąd powszechnie używany jest termin - „zdrowie publiczne”. W przyjętej interpretacji ,rozumiane jest niekiedy jako stan zdrowia populacji oraz jako zespół działań na rzecz zdrowia ludności"13. Jego przedmiotowy zakres obejmuje:

- ,problemy zdrowotne i warunkujące zdrowie (np. choroby zakaźne, choroby powodujące najwyższą umieralność, problemy środowiskowe warunkujące zdrowie, a więc nie tylko tzw. środowisko naturalne,

12 H. Sęk, Subiektywne koncepcje zdrowia, świadomość zdrowotna, a zachowania zdrowotne i promocji zdrowia, w: Promocja zdrowia. Psychologiczne podstawy wdrożeń, pod red. Z. Ratajczak, I. Heszen-Niedojek, Katowice 1997, s. 52.

13 J. Opolski, Zdrowie publiczne - elementy teorii, w: Zdrowie publiczne - wybrane zagadnienia, red. J. Opolski, Warszawa 2011. 
ale także socjo-ekonomiczne, wreszcie problemy organizacyjne oraz ekonomiczne ochrony zdrowia);

- problemy metodologiczne (epidemiologia, socjologia, ekonomika, zarządzanie);

- strategię rozwiązywania problemów zdrowotnych (promocja zdrowia). Zdrowie publiczne jest silnie związane z polityką zdrowotną, gdyż to decyzje polityczne leżą u podstaw wyboru priorytetów oraz dystrybucji środków"14. Tak postrzegane zdrowie poddawane jest działaniom ochronnym o wymiarze globalnym, a nie tylko z perspektywy uwarunkowań występujących w danym kraju czy regionie. Zdrowie stanowi ważny element w zakresie zadań stawianych przed władzą publiczną. Konsekwencją podejmowanych działań jest zapewnienie opieki medycznej poprzez stworzenie odpowiedniego aparatu i mechanizmów rozwiązań pozwalających na powszechność dostępu do oferowanych świadczeń.

We współczesnym świecie szczególny obowiązek został nałożony na instytucje państwowe w zakresie stworzenia systemu rozwiązań zawierających gwarancje w zakresie dostępu do świadczeń medycznych, choćby na podstawowym poziomie. Wyznaczane priorytety w zakresie zwalczania chorób i zagrożeń są uzależniane od regionu podejmowanych działań. Tak postrzegana polityka jest jednym z kluczowych elementów programów partii politycznych, ale przede wszystkim stanowi istotny element działalności władzy wykonawczej.

Pojęcie polityki, nie ma jednej bezwzględnie obowiązującej definicji, stąd wielość podejść w zakresie wyznaczania płaszczyzny obejmującej tę sferę aktywności państwa. Według E. Pietrzak, R. Szczepańskiego, Ł. Zaorski-Sikora ,[...] polityka to artykulacja i sprawowanie władzy państwowej, która w spluralizowanym społeczeństwie musi rozwiązywać wiele różnorodnych problemów celem zapewnienia pokoju i ładu wewnętrznego przez regulowanie wzajemnych stosunków między obywatelami”"15. Konsekwencja politycznej aktywności państwa ${ }^{16}$ jest zapewnienie ładu społecznego m.in. zgodnie z preferowanym systemem wartości społecznie cenionych ${ }^{17}$. $\mathrm{Z}$ tego względu polityka może być

14 Ibidem. s. 10.

15 E. Pietrzak, R. Szczepański, Ł. Zaorski-Sikora, Aksjologia życia publicznego, Łódź 2011, s. 94; por. R. Strzembisz, K. Popielski, Zdrowie jako wyjściowa wartość egzystencji, w: K. Popielski, Wartości w życiu, Lublin 1996, s. 435.

16 Zob. Z. Blok, O polityczności, polityce i politologii, Poznań 2009, s. 31 i n.

17 Zob. Coercion and the State, red. D. A. Reidy, W. J. Riker, Baltimore 2008. 
uważana za „zamierzony i celowy proces zmierzający do realizacji ogólnych założeń w poszczególnych obszarach życia publicznego (oświata, nauka, zdrowie publiczne, pomoc społeczna, ochrona środowiska etc.), które mogą wynikać z polityki rządzących na poziomie centralnym lub terenowym, zaś ich celem jest zaspokajanie potrzeb społecznych [...] lub szerzej - potrzeb interesów państwa, a tym samym potrzeb społecznych (np. polityka w zakresie bezpieczeństwa publicznego)"18. Tak ujmowana polityka, postrzegana poprzez pryzmat aktywności państwowej, służy przede wszystkim społeczeństwu poprzez odpowiednio prowadzone działania o charakterze sektorowym. W kontekście tym, znajduje swoje zastosowanie także polityka społeczna, a co za tym idzie ochrona zdrowia. Opracowany system przedsięwzięć mających na celu stworzenie poczucia bezpieczeństwa zdrowotnego mieszkańców danego obszaru stanowi integralny element polityki bezpieczeństwa. Wiodące znaczenie w tym względzie ma ,[...] brak subiektywnego poczucia zagrożenia, jakie spotyka pacjentów i ich rodziny w sytuacji choroby. Pełną redukcję tego uczucia możemy traktować jako osiagnięcie swego rodzaju dobrostanu - poczucia pełnego bezpieczeństwa zdrowotnego. Wiąże się ono ściśle ze świadomością dostępności opieki zdrowotnej oraz możliwości korzystania z niej w zakresie zaspokajającym potrzebę zdrowotną"19. Realizacja wymaga synergii działań o charakterze informacyjnym, kulturowym, ekonomicznym, społecznym, kadrowym, jak również opracowania instytucjonalnych rozwiązań $\mathrm{w}$ celu równoważenia systemu zdrowotnego.

Polityka prozdrowotna $-\mathrm{z}$ perspektywy działań podejmowanych w Polsce - kwalifikowana jest jako jedna z polityk publicznych. $Z$ tego też względu wynikają obowiązki nałożone na instytucje państwowe i samorządowe. Wielopłaszczyznowość wynika z postrzegania jej w zakresie dokonywanej oceny dotyczącej ochrony zdrowia i polityki prozdrowotnej, postrzeganej jako element polityki społecznej. „Polityka prozdrowotna często kojarzy się z różnymi wielkimi kampaniami w mediach, które mają zwrócić uwagę na takie problemy zdrowotne jak palenie, otyłość, narkomania itd. Jednak nie tylko takie zakrojone na szerszą skalę akcje są wyrazem polityki prozdrowotnej państwa, które ogólnie powin-

18 P. J. Suwaj, Znaczenie prawa $w$ administracji, s. 37, http://ftp.wsap.edu.pl/Nauka_administracji_prawo_a_adm.pdf.

$\overline{9}$ J. Ruszkowski, Zwiększenie bezpieczeństwa zdrowotnego, PROJEKT, Warszawa 2010, s. 3. 
no dbać o krzewienie pewnego zdrowego modelu życia wśród społeczeństwa. Polityka prozdrowotna dotyczy bardzo wielu obszarów naszego życia. Przede wszystkim dotyka takich podstaw, jak styl życia społeczeństwa - to właśnie w ramach tego wycinka polityki prozdrowotnej prowadzi się walkę z nikotynizmem, alkoholizmem, niewielką aktywnością fizyczną obywateli, niewłaściwym odżywianiem oraz takimi patologiami jak narkomania. Skutki tej walki są bardzo różne, jeśli chodzi o tzw. zdrowy styl życia, to ogólnie panuje moda na stosowanie jego założeń, więc, przynajmniej jeśli chodzi o ludzi młodych i wykształconych, założenia polityki prozdrowotnej w tej kwestii przynoszą efekty. [...] Polityka prozdrowotna $\mathrm{w}$ wielu kwestiach zazębia się z polityką społeczną, dotyczy to choćby zaangażowania $\mathrm{w}$ takie sprawy jak szeroko rozumiane środowisko fizyczne i psychiczne"20.

Przypomnieć należy, iż w roku 1948 powołano Światowa Organizację Zdrowia (WHO), jako wyspecjalizowaną agendę Organizacji Narodów Zjednoczonych, której jednym z podstawowych celów było monitorowanie i opracowanie strategii rozwiązań w zakresie przeciwdziałania szerzącym się chorobom. W miarę upływu czasu coraz więcej uwagi zwracano nie tylko na metody leczenia chorób, ale również coraz silniej akcentowano konieczność prowadzenia działań profilaktycznych, edukacji prozdrowotnej.

W przyjętej w roku 1977 przez WHO „Strategii Światowej Zdrowie dla wszystkich w roku 2000” podkreślono, że ,zdrowie jest wartością szczelnie cenioną w społeczeństwach światowych, a dbałość o kondycję mieszkańców winna koncentrować się na:

- ochronie zdrowia ze szczególnym uwzględnieniem profilaktyki jako formy instrumentu wpływającego na świadomość ludzi w zakresie ochrony zdrowia;

- opracowaniu mechanizmów propagujących zdrowy styl życia;

- stworzenie instytucjonalnych rozwiązań umożliwiających korzystanie z powszechnej opieki medycznej ${ }^{21}$.

Tak określony kierunek prac był kontynuowany podczas I Międzynarodowej Konferencji Promocji Zdrowia, która odbyła się w roku w 1986 r. W przyjętej „Karcie Ottawskiej” określono nie tylko podstawowe uwa-

$20 \mathrm{http} / /$ www.cenzuraobywatelska.pl/Polityka_prozdrowotna.html.

21 Zob. http://www.mz.gov.pl/wwwmz/slajd?mr=\&ms $=\& m l=p l \& m i=6 \& m x=0 \& m t=$ $\& m y=6 \& m a=235$. 
runkowania zdrowia, ale wyznaczono zasadnicze kierunki działań, a także wskazano na metody ich realizacji. Po raz kolejny podkreślono, że podmiotem odpowiedzialnym za wdrażanie i finansowanie rozwiązań dotyczących polityki ochrony zdrowia jest przede wszystkim państwo. Koncepcja Nowej Polityki Zdrowotnej wyznaczyła nowe podejście w definiowaniu pojęcia zdrowia i co za tym idzie instytucjonalnych rozwiązań w zakresie jej realizacji. W zaprezentowanej w roku 2000 definicji w sposób szczególny podkreślono konieczność kompleksowego analizowania problemu. Według T. H. Tulchinsky'ego i T. A. Varavikova jest ono: „całościowym podejściem do ochrony oraz promowania zdrowia jednostki i społeczeństwa, opartym na wyważonym działaniu służb sanitarnych, środowiskowych, promocji zdrowia, oraz ukierunkowanych na społeczeństwo działań zapobiegawczych, skoordynowanych z szeroką gamą świadczeń leczniczych, rehabilitacyjnych oraz związanych z długoterminową opieką medyczną. Nowe Zdrowie Publiczne wymaga zorganizowanych programów rządu centralnego oraz samorządów regionalnych i lokalnych. Celem tych programów powinno być kreowanie sprzyjających zdrowiu warunków społecznych, środowiskowych oraz związanych z żywieniem i żywnością,"22. Działanie na rzecz publicznego wymiaru, instytucjonalizacji przyjętych rozwiązań, kompleksowości dokonywanej analizy, długofalowości podejmowanych działań znalazło także akceptację w polskiej doktrynie. M. J. Wy socki, M. Miller ${ }^{23}$, M. Latalski ${ }^{24}$,

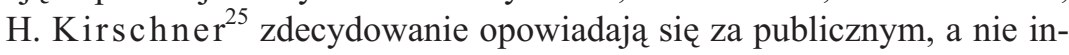
dywidualnym traktowaniem podmiotu ochrony w podejmowanych działaniach na rzecz ochrony zdrowia.

W kolejno opracowywanych dokumentach o europejskim zasięgu uwypuklano znaczenie zdrowia $\mathrm{w}$ procesie budowania globalnego społeczeństwa, np.:

- program „Zdrowie 21. Zdrowie dla wszystkich w XXI wieku” - dokument przyjęty w roku 1998 przez Światową Organizację Zdrowia

22 T. H. Tulchinsky, E. A. Varavikowa, The New public health, Academic Press, New York 2000; zob. M. Lalonde, A New Perspective on the Health of Canadians, A Working Document, Information Canada, Ottawa 1974.

23 Zob. M. J. Wysocki, M. Miller, Nowe zdrowie publiczne w perspektywie 30 lat, w: Zdrowie publiczne..., s. $142-152$.

24 M. Latalski, Zdrowie publiczne, Lublin 1999, s. 6 i n.

25 H. Kirschner, Zdrowie publiczne - ewolucja pojęć, w: Zdrowie publiczne $w$ zmieniajacej się Europie $i$ w Polsce, pod red. J. Nosko, Łódź 2004, s. 121 i n. 
Biuro Regionu Europejskiego określający podstawowe założenia polityki zdrowia dla wszystkich w Regionie Europejskim $\mathrm{WHO}^{26}$;

- a także program Unii Europejskiej w dziedzinie zdrowia publicznego np. decyzja 1786/2002/WE Parlamentu Europejskiego i Rady z dnia 23 września 2002 r. przyjmujaca program działań wspólnotowych $w$ dziedzinie zdrowia publicznego (2003-2008) ${ }^{27}$, czy

- nowa strategia zdrowia publicznego zaproponowana przez Komisję Europejską czy decyzja Parlamentu Europejskiego i Rady ustanawiajaca wspólnotowy program $w$ dziedzinie zdrowia na lata 2007-2013 (COM(2006)234.

- decyzja 1350/2007/WE Parlamentu Europejskiego i Rady z dnia 23 października 2007 r. ustanawiajacej drugi wspólnotowy program działań $w$ dziedzinie zdrowia na lata 2008-201328.

W przyjętych dokumentach za podstawę uznano wyrównywanie poziomów w zakresie oferowanych świadczeń zdrowotnych w poszczególnych krajach europejskich, które to różnice stanowiły następstwa wynikające ze zróżnicowanego poziomu ich rozwoju. Szczególną uwagę zwrócono na konieczność synchronizowania priorytetów w zakresie polityki społecznej, zwłaszcza dotyczącej:

- ,[...] zapewnienia dzieciom i młodzieży pomocy w sytuacjach trudnych, jak na przykład zaburzenia z powodu nadużywania substancji psychoaktywnych czy niechciana ciąża"29;

- zagwarantowania bezpiecznych warunków pracy i promowanie zdrowego środowiska pracy;

- opracowania rozwiązań stwarzających , [...] warunki zdrowego starzenia się poprzez systematyczną i celową promocję i ochronę zdrowia ludzi w ciągu całego ich życia",30;

- zmniejszenia liczby zachorowań i urazów;

26 Tekst opublikowany na stronie http://www.parpa.pl/index.php?option=com_content\&task=view\&id=188\&Itemid=161. Więcej na ten temat pisali: J. B. Karski, W. Kosiarkiewicz, Zdrowie 21. Zdrowie dla wszystkich w XXI wieku, Kraków 2001; C. Włodarczyk, D. Shickle, K. Czabanowska, N. E. Moran, Zdrowie publiczne w krajach europejskich. Wybrane zagadnienia etyczne, Kraków 2007.

27 Dz. U. UE. L.2002.271.1

28 Dz. U. UE. L.2008.354.70, Dz. U. UE. L.2007.301.3.

29 Zdrowie 21 - Zdrowie dla wszystkich w XXI wieku. Podstawowe założenia polityki zdrowia dla wszystkich $w$ Regionie Europejskim WHO, http://www.parpa.pl/index.php?option=com_content\&task=view\&id=188\&Itemid=161.

30 Ibidem. 
- poprawy kondycji zdrowia psychicznego ${ }^{31}$.

Realizacja powyższy założeń wymaga sektorowego podejścia w zakresie ich realizacji. „Oznacza to, że światła polityka gospodarcza, wsparcie społeczne i dobre stosunki społeczne mogą korzystnie wpływać na ludzkie zdrowie. Tak więc, podejście do rozwoju zdrowia zintegrowane i wielodyscyplinarne jest bardziej skuteczne, lepiej zaspokaja potrzeby i jest bardziej efektywne ze względu na koszty aniżeli podejście wąskie, sprowadzające się tylko do sektora zdrowia. Warunki istotne dla życia, a więc odpowiednie warunki ekonomiczne i zdrowotne można stworzyć dzięki dobrej polityce edukacyjnej, zatrudnienia, polityce związanej z organizacją i strukturą przemysłu, polityce fiskalnej i społecznej”. Nie tylko organy naczelne i centralne władzy państwowej uznano za zobowiązane do podejmowania działań, ale dostrzeżono rolę i znaczenie instytucji i organizacji samorządowych, lokalnych, branżowych. Szczególna rola „grup siedliskowych” tj. podstawowych struktur organizacyjnych, w których „ludzie żyją, pracują i bawią się "32 powodowana jest rozeznaniem problemów dotyczących sfery zdrowia na obszarze ich funkcjonowania.

W polityce dbałości o kondycję zdrowotną mieszkańców UE w pierwszym programie w kontekście zdrowia publicznego podjęto działania na rzecz: promocji zdrowia, informacji, edukacji i szkolenia w ramach działań w dziedzinie zdrowia publicznego ${ }^{33}$, plan działania na rzecz zwalczania $^{34}$, program działania $\mathrm{w}$ dziedzinie zapobiegania AIDS oraz niektórym innym chorobom zakaźnym ${ }^{35}$, program działania w dziedzinie zapobiegania uzależnieniu od narkotyków ${ }^{36}$, program działania $\mathrm{w}$ dziedzinie monitorowania zdrowia ${ }^{37}$, program działania $\mathrm{w}$ dziedzinie zapobiegania urazom $^{38}$, program działania $\mathrm{w}$ dziedzinie rzadkich chorób ${ }^{39}$, program działania $\mathrm{w}$ dziedzinie chorób związanych $\mathrm{z}$ zanieczyszczeniem środowiska naturalnego ${ }^{40}$.

31 Ibidem.

32 Ibidem.

33 Dz. U. L 95 z 16.04.1996, s. 1. Decyzja ostatnio zmieniona decyzją 521/2001/WE (Dz. U. L 79 z 17.03.2001, s. 1).

34 Dz. U. L 95 z 16.4.1996, s. 9. Decyzja ostatnio zmieniona decyzją 521/2001/WE.

35 Dz. U. L 95 z 16.4.1996, s. 16. Decyzja ostatnio zmieniona decyzją 521/2001/WE.

36 Dz. U. L 19 z 22.1.1997, s. 25. Decyzja ostatnio zmieniona decyzją 521/2001/WE.

37 Dz. U. L 193 z 22.7.1997, s. 1. Decyzja ostatnio zmieniona decyzją 521/2001/WE.

38 Dz. U. L 46 z 20.2.1999, s. 1.

39 Dz. U. L 155 z 22.6.1999, s. 1.

40 Dz. U. L 155 z 22.6.1999, s. 7. Decyzja ostatnio zmieniona decyzją 521/2001/WE. 
Realizacja celów wyznaczonych w polityce prozdrowotnej wymaga nie tylko podejmowania działań na poszukiwania nowych rozwiązań medycznych, ale za ważny czynnik uznano monitorowanie kondycji zdrowotnej społeczeństwa europejskiego, wczesne ostrzeganie i zwalczanie poważnych zagrożeń dla zdrowia $\mathrm{w}$ związku z transgranicznymi poważnymi zagrożeniami, szczególnie w obszarze: chorób sercowo-naczyniowych, zaburzeń neuropsychiatrycznych, nowotworów, chorób: układu pokarmowego, układu oddechowego, narządów zmysłów, układu mięśniowo-szkieletowego oraz cukrzycy, a także chorób zakaźnych, jak: HIV/AIDS, grypa, gruźlica i malaria. Skuteczność podejmowanych działań wymaga synergii wspólnotowej polityki, nie tylko w obszarze ochrony zdrowia, ale także stworzenia mechanizmów finansowania niezbędnych dla wdrażania opracowanych programów, gwarantujących realizację następujących celów:

- „poprawa bezpieczeństwa zdrowotnego obywateli;

- promocja zdrowia, w tym zmniejszenie nierówności w zakresie zdrowia;

- generowanie i rozpowszechnianie informacji i wiedzy na temat zdrowia"

Tuż po II wojnie światowej ówczesne władze PRL, za jeden z wiodących celów uznały odtworzenie systemu i organizacji służby zdrowia. Począwszy od roku 1948 zmieniły podejście w zakresie traktowania służby zdrowia, bowiem, zrezygnowano z posługiwania się terminem publiczna służba zdrowia na rzecz zakładów społecznej służby zdrowia $^{42}$. Określenie „społeczny” stanowiło swoistego rodzaju poświadczenie wynikające z obowiązującego ustroju społeczno-politycznego, który gwarantował bezpłatną służbę medyczną. Do podmiotów zobowiązanych do wykonywania obowiązków z zakresu ochrony zdrowia zaliczano:

- obligatoryjnie - zakłady lecznicze (zakłady i urządzenia do udzielenia pomocy leczniczej oraz do prowadzenia akcji zapobiegania chorobom) utrzymywane przez Państwo, instytucje państwowe, związki samorządu terytorialnego, instytucje ubezpieczeń społecznych, szpitale na prawach publicznych, a także apteki;

41 Art. 2 ust. 2 decyzja 1350/2007/WE Parlamentu Europejskiego i Rady z dnia 23 października 2007 r. ustanawiajaca drugi wspólnotowy program działań $w$ dziedzinie zdrowia na lata 2008-2013, Dz. Urz. UE 20.11.2007 L 301/3.

42 Ustawa z dnia 28 października 1948 roku o zakładach społecznych służby zdrowia i planowej gospodarce w stużbie zdrowia, Dz. U. 1948, Nr poz. 434. 
- fakultatywnie - zakłady lecznicze utrzymywane przez fundacje, kongregacje, związki i stowarzyszenia religijne, nie obliczone na zysk zakłady innych osób prawnych ${ }^{43}$.

Równolegle z instytucjonalnymi rozwiązaniami wprowadzono dodatkowo działania o charakterze profilaktycznym, np. obowiązkowe szczepienia.

Polskie rozwiązania stanowiły integralną część działań podejmowanych na forum międzynarodowym. Obowiązujący od roku 1948 w Polsce model społecznej służby zdrowia nawiązywał do definicji przyjętej w opublikowanej w okresie II Rzeczypospolitej ustawy z dnia 15 czerwca 1939 r. o publicznej służbie zdrowia, w której za wiodący cel uznano „[...] wykonywanie pieczy nad zdrowiem ludności”,44, „Publiczna służba zdrowia obejmuje w szczególności sprawy: zwalczanie chorób i zapobieganie im, zakładów leczniczych i leczniczo-zapobiegawczych, uzdrowisk, cmentarzy, opieki higieniczno-lekarskiej nad matką i dzieckiem, zwłaszcza w szkołach powszechnych i dokształcających, higieny szkolnej, wychowania fizycznego, opieki nad koloniami i półkoloniami, zaopatrywania ludności w wodę i usuwania nieczystości, dozoru sanitarnego nad artykułami żywności i przedmiotu użytku i higieny bytowania i pracy, kąpielisk, higieny środków lokomocji, nadzoru sanitarnego nad wyrobem i obrotem środków leczniczych i zapobiegawczych, aptek i drogerii, nadzoru mad zawodami czynnymi w zakresie służby zdrowia"45. Mając na względzie konieczność zagwarantowania systemu instytucjonalnych rozwiązań powołano Ministra Opieki Zdrowotnej, zaś środki niezbędne dla jego funkcjonowania winny być zagwarantowane przez władze administracji rządowej i samorządu ${ }^{46}$. Przyjęte stanowisko odzwierciedlało powszechnie aprobowaną, w ówczesnym świecie tendencję do przypisywania państwu szczególnej roli w zakresie dbałości o kondycję zdrowotną społeczeństwa i tworzących go jednostek. Stanowiska prezentowane przez amerykańskich uczonych m.in., przez C. E. A. Winslow'a ${ }^{47}$, E. D. Achesona ${ }^{48}$ czy kanadyjskiego ministra ds. zdrowia Marca

${ }^{43}$ Art. 1-4 ustawy z dnia 28 października 1948 roku o zakładach społecznych stużby...

${ }_{44}$ Art. 1 ustawy o publicznej stużbie zdrowia, Dz. U. 1939, Nr 54, poz. 342.

45 Art. 1 ust. 2 ustawy o publicznej stużbie...

${ }^{46}$ Art. 3 i 4 ustawy o publicznej stużbie...

47 C. E. A. Winslow, The untilled fields of public health, „Science N.S.” 1920, nr 51, s. 22 i n.

${ }^{48}$ E. D. Acheson, Public health in England. Report of the Committee of Inquiry into the future development of the public health function, HMSO, London 1988. 
LaLonde'a ${ }^{49}$, wyraźnie wskazywały na konieczność podjęcia systemowych rozwiązań mających na celu zapobieganie chorobom m.in. poprzez stworzony mechanizm instytucjonalnych rozwiązań, opracowanie metod leczenia, ale również profilaktykę, edukację obywatelska, prowadzoną przez wyspecjalizowane instytucje i organizacje. W ten sposób pojęcie „zdrowie publiczne” zyskało normatywny wymiar. Pojęcia: „zdrowie społeczne” i „zdrowie publiczne” zostały przez Sąd Najwyższy potraktowane jako synonimy. W takim ujęciu chroniona jest przede wszystkim „Zdrowotność ludzkiej populacji”, która zajmuje priorytetowe miejsce względem ochrony życia i zdrowia człowieka $^{50}$.

Uprawnieniem człowieka jest zatem roszczenie adresowane względem instytucji państwowych do zagwarantowania prawidłowego rozwoju fizycznego i psychicznego. Konstytucyjne gwarancje dotyczące praw przysługujących obywatelom wyraźnie wskazuja, że każdy ma prawo do ochrony zdrowia (art. 68). Szczególną troską obdarzono obywateli, a zwłaszcza obowiązane do zapewnienia szczególnej opieki zdrowotnej dzieciom, kobietom ciężarnym, osobom niepełnosprawnym i osobom w podeszłym wieku, którym władze publiczne zapewniają równy dostęp do świadczeń opieki zdrowotnej finansowanej ze środków publicznych. Beneficjentami świadczeń są wszyscy niezależnie od wieku, rasy, płci pochodzenia, miejsca zamieszkania, wykształcenia czy statusu materialnego. Tak określone obowiązki podyktowane są m.in. troską o stan zdrowia społeczeństwa, a co za tym idzie zapewnienie rozwoju narodu, jak również względami humanitarnymi. „Z konstytucyjnego prawa do powszechnej ochrony zdrowia (art. 68 ust. 1 Konstytucji RP) nie wynika wprost uprawnienie do uzyskania zaświadczenia o stanie zdrowia" ${ }^{\text {"5 }}$. Prawo to podlega pewnym ograniczeniom, bowiem ,z konstytucyjnego prawa do powszechnej ochrony zdrowia i równego dostępu do świadczeń opieki zdrowotnej finansowanej ze środków publicznych (art. 68 ust. 1 i 2 Konstytucji) nie wynika roszczenie świadczeniodawcy do za-

49 M. LaLonde, A New Perspective on the Health of Canadians, A Working Document, Information Canada, Ottawa 1974.

50 Szerzej na ten temat: M. Sagan, Glosa do uchwaty Sqdu Najwyższego z dnia 27 października 2005 r., sygn. I KZP 32/05, „Prokuratura i Prawo” 2006, nr 5, s. $157-173$.

51 Wyrok Naczelnego Sądu Administracyjnego w Warszawie z dnia 19 stycznia 2009, II OSK 101/08, LEX nr 515987. 
mawiającego, ponieważ warunki udzielania świadczeń określa ustawa" ${ }^{\text {" }}$. zatem uprawnienia pacjenta będą wynikały m.in. z treści zawartej umowy z uprawnioną do tego instytucją. Ograniczenie to nie będzie zapewne miało zastosowania do tych wszystkich zabiegów, których celem jest ratowanie życia ${ }^{53}$.

Politykę ochrony zdrowia publicznego determinuje obowiązujący system ubezpieczeń, bowiem stanowi on wyraz podejmowanych działań w zakresie przysługujących świadczeń zwłaszcza w kontekście korzystania z oferty bezpłatnej opieki zdrowotnej świadczonej w ramach Narodowego Funduszu Zdrowia ${ }^{54}$. Uprawnionym do korzystania ze świadczeń jest nie tylko podmiot ubezpieczony, ale także bezrobotny, którego koszty leczenia ponosi państwo, zatem każdy mający miejsce zamieszkania na terenie RP, mający lub nieposiadający obywatelstwa polskiego ${ }^{55}$. Pamiętać jednakże należy, iż w dualnym systemie organizacji służby zdrowia w Polsce - równoległe funkcjonowanie służby medycznej publicznej i prywatnej - szczególne obowiązki w zakresie świadczenia medycznego spoczywają na służbie publicznej. Przypomnieć należy, iż wprowadzane w latach 90-tych minionego stulecia zmiany wprowadzały obowiązkowe ubezpieczenia na zdrowie, zmianę systemu organizacji służby medycznej (rejestr usług medycznych - RUM), a także reformę dotyczącą funkcjonowania aptek - wdrażano system leków refundowanych. Nie ulega wątpliwości, iż zapoczątkowany wówczas system zmian organizacji służby medycznej nie zyskał poparcia i kolejne rządy: Jerzego Buzka, Leszka Millera, Marka Belki, Jarosława Kaczyńskiego nie sfinalizowały zmian, a z części założeń musiały zrezygnować. Pomimo lansowanego przez rząd J. Buzka hasła ,pieniądz będzie szedł z pacjentem" nie udało się stworzyć systemu na miarę oczekiwań społecznych. Skomplikowany system obowiązujących w służbie zdrowia procedur nie znajduje rozwiązania także aktualnie. Polityka rządu Donalda Tuska budzi niezadowolenie wśród społeczeństwa, jak również służb medycznych

52 Wyrok Sądu Najwyższego z dnia 15 grudnia 2004 r. IV CK 361/04, LEX nr 258677.

53 Wyrok Sądu Apelacyjnego w Poznaniu z dnia 23 maja 2006 r. I ACa 1266/05, LEX nr 214245.

54 Zakres działalności resortu określa rozporządzenie Prezesa Rady Ministrów z dnia 29 września 2004 r. w sprawie nadania statutu Narodowemu Funduszowi Zdrowia (Dz. U. 2004.213.2161).

55 Ustawa z dnia 27 sierpnia 2004 r. o świadczeniach opieki zdrowotnej finansowanych ze środków publicznych, Dz. U. 2008.164.1027 t.j. 
czy w zakresie zasad funkcjonowania systemu leków refundowanych, czego wyrazem były protesty u progu 2012 r., m.in. aptekarzy i lekarzy. Zgodnie z przyjętymi ,zasadami polityki ochrony zdrowia podstawową jednostką systemu opieki zdrowotnej jest lekarz medycyny rodzinnej, do którego chorzy udają się najpierw, niezależnie od dolegliwości. Dopiero ten lekarz wypisuje skierowanie do poradni specjalistycznej bądź do szpitala, jeśli jest to potrzebne. Rozwiązanie to budzi wiele kontrowersji i często staje się tematem różnych dyskusji politycznych, jednak póki co instytucja lekarza rodzinnego ma się bardzo dobrze i kolejne rządy raczej nie dążą do zmiany tego systemu. Warto jeszcze dodać, że pod względem prawno-politycznym zakłady opieki zdrowotnej podlegaja jednostkom samorządu terytorialnego, które zasadniczo decydują o otwarciu bądź zamknięciu takiego właśnie zakładu. W myśl założeń polityki ochrony zdrowia realizowanej przez państwo, również samorząd terytorialny decyduje o przyznaniu określonych dotacji finansowych na działalność zakładów opieki zdrowotnej"56.

W zakresie realizacji celów wyznaczonych przez opracowany przez WHO i UE program ochrony zdrowia, także w Polsce podjęto działania mające na celu adaptację kierunków przyjętych w polityce międzynarodowej ochrony zdrowia do polskich realiów. Już w latach 1990 podjęto próbę określenia podstawowych założeń dla Narodowego Programu Zdrowia, którego koncepcja poddawana była weryfikacji kolejno w latach 1993, 1996. W ślad za tym w kolejno stanowionych rozwiązaniach normatywnych podkreślano publiczny wymiar zdrowia: ustawa $\mathrm{z}$ dnia 24 sierpnia 2001 r. o zmianie ustawy o Inspekcji Sanitarnej oraz niektórych innych ustaw ${ }^{57}$, Rozporządzenie Ministra Zdrowia z dnia 6 sierpnia 2001 r. w sprawie specjalizacji lekarzy stomatologów w podstawowej dziedzinie medycyny - zdrowie publiczne ${ }^{58}$ czy zmieniająca system ubezpieczeń społecznych ustawa z dnia 3 grudnia 1999 r. o zmianie ustawy o powszechnym ubezpieczeniu zdrowotnym ${ }^{59}$, ustawa $\mathrm{z}$ dnia 27 sierpnia 2004 r. o świadczeniach opieki zdrowotnej finansowanych ze środków publicznych ${ }^{60} \mathrm{i}$ inne akty prawne.

56 http://www.cenzuraobywatelska.pl/Polityka_ochrony_zdrowia.htm.

57 Dz. U. Nr 128, poz. 1407.

58 Dz. U. Nr 83, poz. 903.

59 Dz. U. 99.109.1236.

60 Dz. U. 2004.210.2135. 
Dotychczasowe doświadczenie okazało się być pomocne w opracowaniu kolejnych strategii w latach 2003, 2006. Doświadczenie i wiedza stały się źródłem dla opracowania długofalowego programu ochrony zdrowia w Polsce na lata 2007-2013 przyjętego przez Radę Ministrów, który został następnie wydłużony w zakresie realizacji na kolejne dwa lata. Cel główny opisany jako „Poprawa zdrowia i związanej z nim jakości życia ludności oraz zmniejszanie nierówności w zdrowiu” winien być osiagany przez:

- kształtowanie prozdrowotnego stylu życia społeczeństwa;

- tworzenie środowiska życia, pracy i nauki sprzyjającego zdrowiu;

- aktywizowanie jednostek samorządu terytorialnego i organizacji pozarządowych do działań na rzecz zdrowia.

NPZ jako integralna część Strategii wyznacza kierunki polityki prozdrowotnej w Polsce do 2015 r. Ministerstwo Zdrowia ${ }^{61}$ wspólnie ze wspierającymi w zakresie realizacji wyznaczonych zadań organami administracji publicznej wszystkich szczebli i organizacjami pozarządowymi podejmują działania ,[...] na rzecz poprawy zdrowia populacji i wyrównania różnic w tym zakresie",62 . "Rolą rządu jest natomiast tworzenie warunków sprzyjających realizacji działań podejmowanych przez wszystkie ww. podmioty. Tylko przy wspólnym wysiłku i ścisłym współdziałaniu obywateli możemy poprawić stan zdrowia Polaków, a tym samym jakość ich życia"63.

Nie tylko organy administracji rządowej zobowiązane są do podejmowania działań na rzecz ochrony zdrowia, ale zadania takie wskazane zostały także w regulacjach określających kompetencje administracji

61 Zakres działalności resortu określa rozporządzenie Prezesa Rady Ministrów z dnia 29 września 2004 r. w sprawie nadania statutu Narodowemu Funduszowi Zdrowia, Dz. U. 2004, Nr 213, poz. 2161.

62 Narodowy Program Zdrowia, załącznik do uchwały Nr 90/2007, Rady Ministrów z dnia 15 maja 2007 r., s. 8.

63 Ibidem, s. 10. Szczególne zadania w tym względzie zostały wskazane rozporządzeniem Prezesa Rady Ministrów z dnia 27 kwietnia 2004 r. w sprawie przygotowania systemu kierowania bezpieczeństwem narodowym, Dz. U. 2004.98.978, par. 22 ww. aktu, „§ 22 . W ramach przygotowywania systemu kierowania minister właściwy do spraw zdrowia przygotowuje, w uzgodnieniu z Ministrem Obrony Narodowej i ministrem właściwym do spraw wewnętrznych, plan zabezpieczenia świadczeń zdrowotnych na potrzeby Prezydenta Rzeczypospolitej Polskiej, Prezesa Rady Ministrów, ministrów oraz centralnych organów administracji rządowej i jednostek organizacyjnych zabezpieczających ich funkcjonowanie w rejonach głównych i zapasowych stanowisk kierowania”. 
samorządowej. Zgodnie z art. 6 ustawy o samorządzie terytorialnym zadaniem gminy jest rozstrzyganie wszystkich spraw publicznym o znaczeniu lokalnym, zakreślonych w obowiązujących aktach prawnych. Do

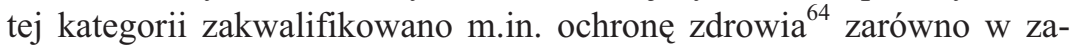
kresie wykonywania zadań własnych jak np. rozwiązywanie problemów alkoholowych $^{65}$ czy zleconych, np. w zakresie ochrony zdrowia psychicznego $^{66}$. Realizacja zadania dokonywana jest poprzez realizowanie własnych projektów i programów prozdrowotnych lub przyjęcie wymiaru uczestnika realizacji działania o charakterze ogólnokrajowym lub regionalnym. Zadania publiczne o charakterze ponadgminnym w zakresie określonym aktami prawnymi, zatem m.in. promocji i ochrony zdrowia stanowią przedmiot działań powiatu ${ }^{67}$. Wśród wielu zadań wyróżnić należy przede wszystkich tworzenie planu powiatowego zabezpieczeń medycznych, nadzór nad zakładami opieki zdrowotnej, zagwarantowanie ratownictwa medycznego, ale również co z punktu widzenia omawianego zagadnienia ma ważne znaczenie - wykonywanie zadań dotyczących profilaktyki zdrowotnej. Dbałość o kondycję regionalnej wspólnoty samorządowej na obszarze stanowi prerogatywę samorządu wojewódzkiego ${ }^{68}$. Działania koncentrują się m.in. na realizacji programów profilaktycznych na danym obszarze, w celu zapobiegania schorzeniom. Kierując się dyrektywą, iż wiodącym celem ,programów profilaktycznych jest wykonanie badań w miejscu zamieszkania pacjentów, co umożliwia wyrównanie szans w dostępie do specjalistycznych badań diagnostycz-

64 Art. 7 ust. 1 pkt 5 ustawy o samorzqdzie gminnym Dz. U. 2001.142.1591 t.j. z zm.; zob. rozporządzanie Prezesa Rady Ministrów z dnia 22 czerwca 2001 r. w sprawie wykazu samodzielnych publicznych zakładów opieki zdrowotnej, które zostały przejęte przez gminy, powiaty i samorzady województw, Dz. U. 2001.65.659; rozporządzenie Ministra Zdrowia z dnia 10 października 2001 r. w sprawie zasad $i$ warunków, jakim powinien odpowiadać minimalny plan zabezpieczenia ambulatoryjnej opieki zdrowotnej, Dz. U. 01.121.1315 ze zm.

65 Zob. ustawa z dnia 26 października 1982 r. o wychowaniu w trzeźwości i przeciwdziałaniu alkoholizmowi, Dz. U. 02.147.1231ze zm.

66 Zob. ustawa z dnia 19 sierpnia 1994 r. o ochronie zdrowia psychicznego, Dz. U. 94.111 .535 ze zm.

67 Zob. art. 4 ust. 1 pkt 2 ustawy z dnia 5 czerwca 1998 r. o samorzqdzie powiatowym, Dz. U. 2001.142.1592 t.j. ze zm.; ustawa z dnia 13 października 1998 r. Przepisy wprowadzajace ustawy reformujace administracje publicznq, Dz. U. 98.133 .872 ze $\mathrm{zm}$.

${ }^{68}$ Ustawa z dnia 5 czerwca 1998 r. o samorzqdzie województwa, Dz. U. 2001.142.1590 t.j. ze zm. 
nych $[\ldots]^{69}$ jednostki administracji publicznej realizują programy własne ${ }^{70}$ jak również o zasięgu ogólnokrajowym. Instytucje samorządowe samodzielnie albo wspólnie z działającymi na danym obszarze organizacjami pozarządowymi realizują wskazane cele.

Katalog chorób cywilizacyjnych wciąż ulega rozszerzeniu, stąd intensyfikacja działań na rzecz zapobiegania powstawaniu zagrożeniom poprzez kształtowanie profilaktyki prozdrowotnej, jak również coraz większy nacisk położony na edukację $\mathrm{w}$ zakresie uświadamiania społeczeństwa co do powstających zagrożeń i przeciwdziałania chorobom. Profilaktyka $^{71}$ pojmowana jest jako czynnik zapobiegający powstawaniu zagrożeń zdrowia poprzez odpowiednio ukształtowany system rozwiązań pozwalających m.in. na wzrost świadomości ich powstawania, zwłaszcza wśród osób z tzw. „ryzyka chorobowego”. Pojęcie to często utożsamiane jest z promocją zdrowia, aczkolwiek mechanizmy działań promocyjnych mogą być m.in. instrumentem realizacji zadań profilaktycznych (por. rys. 1 różnice między profilaktyką i promocją).

Ochrona zdrowia stanowi jeden $\mathrm{z}$ istotnych czynników całokształtu przedsięwzięć podejmowanych w celu zagwarantowania jak najlepszej kondycji zdrowotnej mieszkańców określonego obszaru. Służyć temu mają także opracowane programy profilaktyczne, m.in.:

- Narodowy Program Profilaktyki i Leczenia Chorób Układu Sercowo-Naczyniowego - Polkard realizowany w latach 2007-2015,

- Narodowy Program Zwalczania Chorób Nowotworowych realizowany w latach 2007-2015,

- Program badań przesiewowych noworodków w Polsce 2006-2015,

- Program psychiatrycznej opieki zdrowotnej 2006-2008,

- Program eliminacji niedoboru jodu na lata 2006-2008,

69 Programy polityki zdrowotnej, Urząd Marszałkowski Województwa Wielkopolskiego w Poznaniu, http://www.umww.pl/urzad/departamenty/departament-ochrony-zdrowia-i-przeciwdzialania-uzaleznieniom/wydzial-zdrowia-publicznego.html.

70 Zob. uchwała nr 1338 /2011 Zarządu Województwa Wielkopolskiego z dnia 25 listopada 2011 roku, http:/www.umww.pl/pub/uploaddocs/13.-2011-uchwala-zww-.1347524465.pdf; Podsumowanie działań w zakresie HIV/AIDS podjętych przez Urzad Marszałkowski Województwa Wielkopolskiego w Poznaniu w ramach Harmonogramu realizacji Krajowego Programu Zwalczania AIDS i Zapobiegania Zakażeniom HIV opracowanego na lata 2007-2011, http:/www.umww.pl/pub/uploaddocs/podsumowanie-dzialan-w-zakresie-hiv-2007-2011.1347524465.pdf.

71 Szerzej na temat pojęcia profilaktyka, m.in. w: A. Czupryna, S. Poździoch, A. Ryś, W. C. Włodarczyk, Zdrowie publiczne, Kraków 2001. 


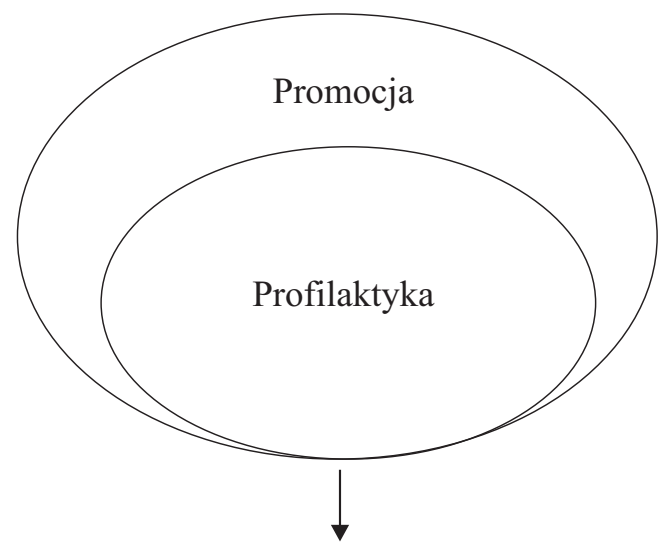

Obszar wzajemnego przenikania się działań, np. szczepienia ochronne, podawanie żelaza i witamin

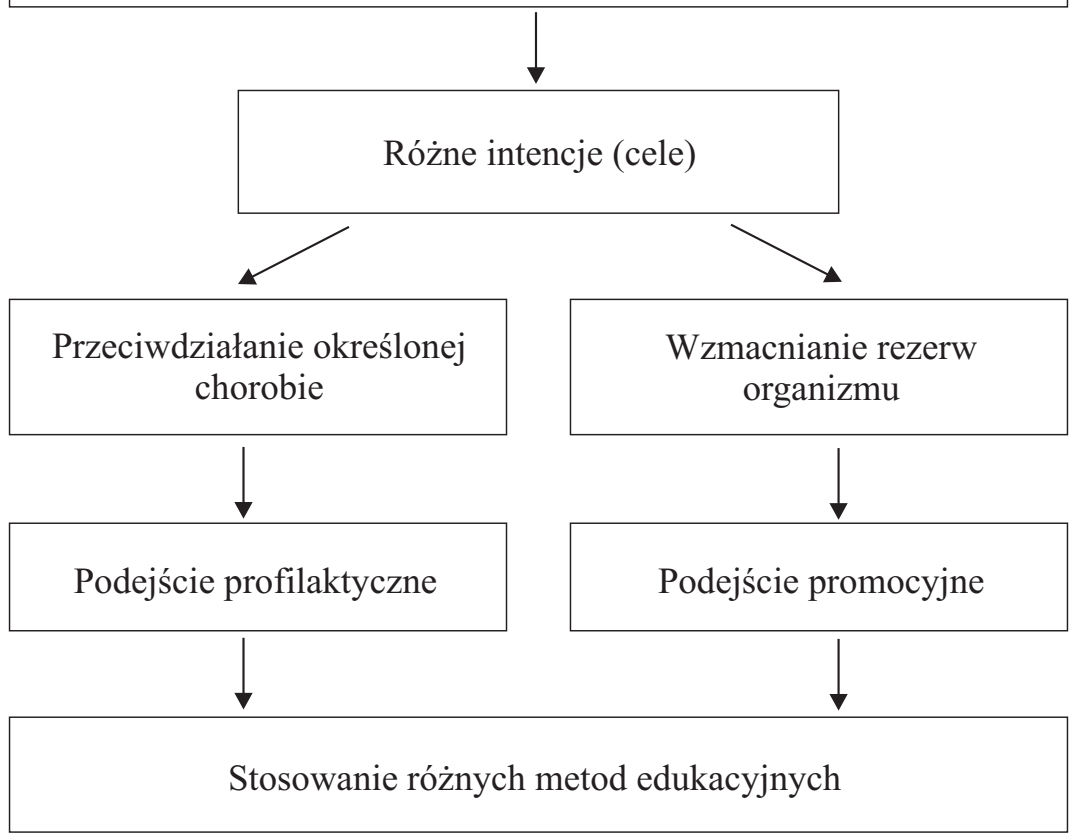

Rys. 1. Różnice między profilaktyką i promocją

Źródło: Cyt. za Założenia Planu Zdrowotnego Miasta Poznania na lata 2010-2014 jako dokumentu strategicznego w planowaniu dlugookresowej polityki zdrowotnej dla mieszkańców Poznania, Poznań 2009, s. 9. Opracowano na podstawie: A. Czupryna, S. Poździoch, A. Ryś, W. C. Włodarczyk, Zdrowie publiczne, Kraków 2001. 
- Narodowy program rozwoju medycyny transplantacyjnej POLGRAFT $^{72}$.

Poziom zagrożenia nowotworami we współczesnym świecie jest bardzo wysoki zarówno u kobiet, jak i płci przeciwnej. „Zmiany w strukturze ludności, polegające na zwiększeniu liczebności grup wiekowych, w których zachorowalność jest szczególnie wysoka (6,5\% ludności w wieku 65 lat i więcej w roku 1963, 11,3\% w 1996, 12,4\% w 2001, $13,2 \%$ w 2005 oraz prognozy na lata 2010 i 2020 odpowiednio $14 \%$ i 19\%) wskazują, że liczba zachorowań na nowotwory w okresie najbliższych dziesięciu lat będzie wzrastać" ${ }^{, 73}$. W odniesieniu do mężczyzn zauważalny jest wzrost ryzyka chorób układu moczowo-płciowego. Mimo, iż powszechnie uważa się, że ,Zdrowie to jedno z podstawowych dóbr cenionych w polskim społeczeństwie. Na zachowanie dobrego zdrowia jako jedną z najważniejszych wartości codziennego życia wskazuje niemal trzy piąte badanych (59\%). Wyżej cenione jest jedynie szczęście rodzinne (76\% wskazań) ${ }^{974}$, jednakże deklarowany system wartościowania nie zawsze znajduje potwierdzenie w codziennych zachowaniach. „Mimo, iż istnieje dość silne społeczne przekonanie o tym, że dbanie o własne zdrowie nie jest dla Polaków bardzo ważne, paradoksalnie zdecydowana większość badanych (80\%) zalicza się do osób, które troszczą się o stan swego zdrowia. W porównaniu z rokiem 1993 ich odsetek zwiększył się aż o 22 punkty. Jednak tylko $17 \%$, czyli o 3 punkty więcej niż czternaście lat temu, stanowią ci, którzy nie mają wątpliwości co do swojego zaangażowania na rzecz prozdrowotnego stylu życia. Do braku troski o swoje zdrowie przyznaje się niespełna co piąty badany (19\%), a więc o połowę mniej niż w 1993 roku"

Postęp w dziedzinie medycyny okazuje się być ważnym, ale nie jedynym czynnikiem wpływającym na kondycje zdrowotną jednostek. Nie bez znaczenia dla dbałości o stan zdrowia pozostaje postęp cywilizacyjny. Z jednej strony znacząco poprawiły się warunki bytowania, ale równocześnie pojawiły się nowe zagrożenia, wynikające m.in. ze stylu życia, tak w odniesieniu do aktywności fizycznej, jak i higieny żywienia.

72 Efekty wdrażanych systemów już znajdują odzwierciedlenie w statystykach. Dane wskazują na spadek współczynnika umieralności niemowląt, śmierci powodowanej niewydolnością krążenia, wydłużenie okresu życia mieszkańców Polski.

73 J. Rutkowski, Zwiększenie bezpieczeństwa..., s. 22.

74 Zdrowie i zdrowy styl życia w Polsce, CBOS, Warszawa 2007, BS/138/2007, s. 1.

75 Ibidem, s. 10. 
Kobiety częściej korzystają z badań profilaktycznych względem mężczyzn. Pewne zachowania w ostatnich latach stały się konsekwencją dobrze prowadzonych kampanii profilaktycznych i informacyjnych, np., badania mammograficzne, a także wysokiego stopnia zaangażowania władz ogólnokrajowych i regionalnych.

Inaczej sytuacja kształtuje się w odniesieniu do mężczyzn, którzy często kontakt z lekarzem klasyfikują, jako ostatni z możliwych wyborów. Mimo, iż wiele mówi się na temat chorób nowotworowych zarówno wśród kobiet jak i płci przeciwnej, to jednak, mężczyźni o wiele rzadziej korzystają z możliwości uczestniczenia z badaniach profilaktycznych, zwłaszcza gdy idzie o choroby związane z drogami płciowo-moczowymi. Badania prowadzone w ostatnich latach tak w Europie jak i Polsce, wykazały, że stopień ryzyka zachorowalności na ten rodzaj nowotworów wśród mężczyzn powyżej 45 roku życia wzrasta.

„Dane epidemiologiczne wskazują, że w Polsce w roku 2007 żyło ponad 6,8 mln mężczyzn w wieku powyżej 45 i więcej lat [...]. W tej grupie wieku występuje rocznie blisko 14000 przypadków nowych zachorowań na nowotwory układu moczowo-płciowego, z czego 1/3 rozpoznawana jest u mężczyzn aktywnych zawodowo. Szacuje się, że 51000 mężczyzn w Polsce żyje z tą chorobą zdiagnozowaną w ostatnich pięciu latach. Istotna część z tych osób może wskutek choroby zostać wykluczona z aktywności zawodowej"76. Dodatkowo skuteczność leczenia w Polsce raka pęcherza moczowego wynosi 57\%, co sprawia, że relatywnie do innych krajów europejskich sytuuje nas na jednym $\mathrm{z}$ ostatnich miejsc ${ }^{77}$. W roku 2008 liczba zgonów powodowanych chorobami gruczołu krokowego, nerek, pęcherza moczowego wahała się około 20\%. Odpowiednio w skali europejskiej w roku 2008, ,[...] w populacji męskiej zanotowano około 388700 nowych przypadków i 70800 zgonów z powodu tego nowotworu" $" 78$ (por. rys. 2 i rys. 3).

Trendy zachorowalności szczególnie zauważane były w grupie wiekowej powyżej 45 roku i wykazywały tendencje wzrostową w poszczególnych grupach wiekowych.

$\mathrm{Z}$ analizy dokonanej w Wielkopolsce wynika, że również mieszkańcy tego regionu często zapadają na choroby nowotworowe (por. rys. 4).

76 Program projektu M 45+, Materiały MZ, Warszawa 2011, s. 8.

77 Więcej na ten temat w: U. Wojciechowska, J. Didkowska, W. Zatoński, Nowotwory złośliwe w Polsce $w$ roku 2006, Warszawa 2009.

78 Program..., s. 35. 


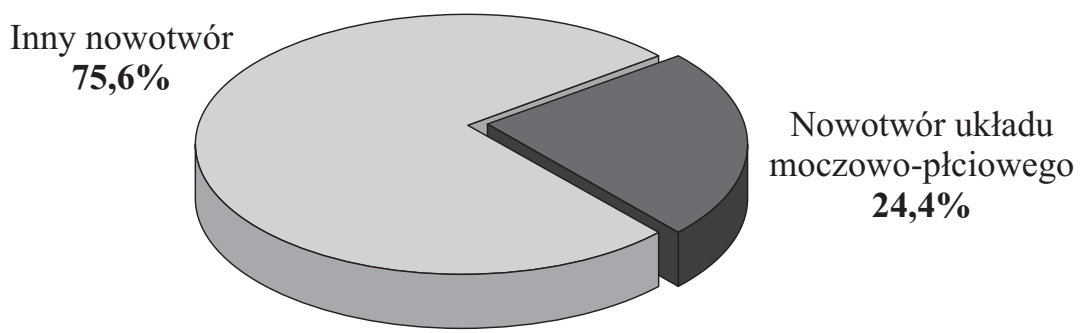

Rys. 2. Udział zachorowań na nowotwór układu moczowo-płciowego w ogólnej liczbie mężczyzn $45+\mathrm{z}$ chorobą nowotworową

Źródło: Program projektu..., s. 63.

\section{Nowotwór nerki}

\section{$15,4 \%$}

Nowotwór gruczołu

krokowego

$54,9 \%$

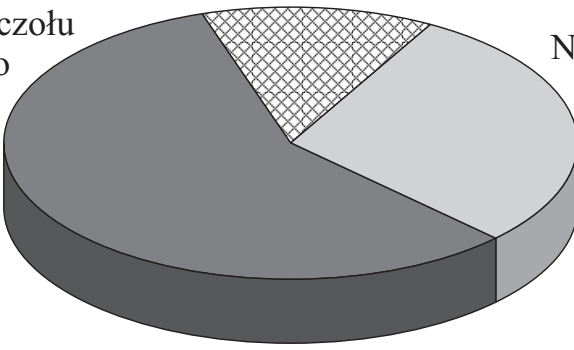

Nowotwór pęcherza moczowego

$29,7 \%$

Rys. 3. Zachorowania na nowotwory układu moczowo-płciowego Źródlo: Program projektu..., s. 63.

Jak wynika z rysunku 4 ,wśród osób dorosłych (36-69) i starszych $(70+)$ istotnym zagrożeniem są choroby nowotworowe. Tylko w roku 2008 na ten rodzaj schorzenia zachorowało ponad 80000 osób $^{79}$. Współczynnik zachorowalności nie ulega zmianie w zależności od miejsca zamieszkania danej osoby i panujących czynników ekologicznych ${ }^{80}$.

W celu ustalenia czynników mający wpływ na wzrost zagrożenia chorobą nowotworową uwzględniono kryteria tj. wiek, miejsce zamieszkania, warunki pracy zawodowej.

79 Zob. Informator liczbowy ochrony zdrowia województwa wielkopolskiego za 2008 rok, Wielkopolskie Centrum Zdrowia Publicznego w Poznaniu, Poznań 2009.

80 Por. Dane zamieszczone w: Program projektu $45+\ldots$, s. 64-65. 


\section{Płuc} $20 \%$

Gruczołu krokowego

$$
\square
$$
Jelita grubego

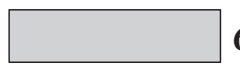

$6 \%$

Pęcherza moczowego
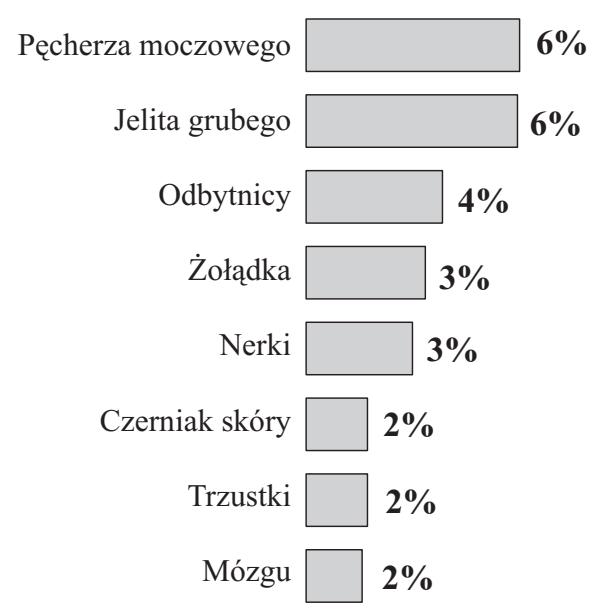

$6 \%$

Rys. 4. Zachorowania na najczęstsze nowotwory złośliwe wśród mężczyzn zamieszkałych w Poznaniu w 2006 roku

Źródło: E. Dybowska, D. Kamińska, M. Szymanowicz, Założenia Planu Zdrowotnego Miasta Poznania na lata 2010-2014 jako dokumentu strategicznego $w$ planowaniu dtugookresowej polityki zdrowotnej dla mieszkańców Poznania, Poznań 2009, s. 32.

Przyjęte granice wiekowe dawały podstawy do zwrócenia uwagi na dwie grupy podmiotów: tj. aktywnych zawodowo, jak również osoby nieaktywne zawodowo. Elementem uzasadniającym dokonany podział był także styl życia, aktywny w przypadku osób czynnych zawodowo, szczególnie zatrudnionych w zawodach o tzw. podwyższonym ryzyku zachorowalności ${ }^{81}$, jak i o zmniejszonym poziomie aktywności zwłaszcza wśród osób należących do grupy podmiotów w wieku emerytalnym. Osoby w wieku emerytalnym najczęściej wolny czas spędzają:

- oglądając telewizję (98\%),

- spotykając się ze znajomymi i przyjaciółmi w domu (87\%) lub poza domem $(76 \%)$,

- uczestnicząc w nabożeństwach liturgicznych (81\%),

81 Do tej kategorii zakwalifikowano osoby zatrudnione w przemyśle: gumowym, tworzyw sztucznych, metalurgicznym koksowniczym hutniczym, paliwowo-energetycznym. Zob. Program projektu..., s. 12. 
- słuchając radia $(81 \%)^{82}$.

Statycznej formie spędzania wolnego czasu towarzyszy często konsumpcja, co podnosi poziom ryzyka zachorowalności, z uwagi na konsekwencje powodujące m.in. nadwagę.

Nie bez znaczenia pozostaje także kontekst świadomości zachorowań na choroby nowotworowe. Wśród objętych programem profilaktycznym grupy podmiotów 40\% wyrażało obawy zachorowania na nowotwór. Zaskakujące okazały się być wyniki dotyczące świadomości istnienia choroby, bowiem 7\% uważało, że nie chce wiedzieć o jej istnieniu, czynnik ten był dwukrotnie wyższy w przypadku osób wykonujących zawody o podwyższonym ryzyku zachorowalności, obawiano się bowiem m.in. samej procedury leczenia $(4,1 \%)^{83}$.

Tabela 2

Nowotwory narządów moczowo-płciowych i ich determinanty

\begin{tabular}{|c|c|c|c|c|}
\hline $\begin{array}{c}\text { Rodzaj } \\
\text { schorzenia }\end{array}$ & $\begin{array}{c}\text { Deklarowane przyczyny } \\
\text { zachorowań }\end{array}$ & $\begin{array}{c}\text { Grupa ryzyka z uwagi } \\
\text { na wiek (najwyższy } \\
\text { wspólczynnik } \\
\text { zachorowalności) }\end{array}$ & $\begin{array}{l}\text { Liczba } \\
\text { zachoro- } \\
\text { wań }\end{array}$ & $\begin{array}{l}\text { Liczba } \\
\text { zgonów }\end{array}$ \\
\hline $\begin{array}{l}\text { Gruczoł } \\
\text { krokowy }\end{array}$ & $\begin{array}{l}\text { wiek, nadwaga, genetyka, } \\
\text { niewłaściwa dieta, palenie } \\
\text { tytoniu, infekcje }\end{array}$ & 55-79 lat & 8268 & 3900 \\
\hline Rak nerki & $\begin{array}{l}\text { niewłaściwa dieta, ekspo- } \\
\text { zycja zawodowa }\end{array}$ & $50-79$ & 2320 & 1530 \\
\hline $\begin{array}{l}\text { Nowotwór } \\
\text { pęcherza } \\
\text { moczowego }\end{array}$ & $\begin{array}{l}\text { palenie tytoniu, ekspozycja } \\
\text { zawodowa, terapia farma- } \\
\text { kologiczna, infekcje }\end{array}$ & po $55-79$ & 4539 & 2354 \\
\hline
\end{tabular}

Źródło: Opracowanie własne na podstawie danych uzyskanych z Ministerstwa Zdrowia.

Powyższa tabela pozwala na dokonanie gradacji okoliczności z punktu widzenia czynników:

- behawioralnych,

- zawodowych.

Do pierwszej zakwalifikować należy m.in.: styl życia osoby, palenie wyrobów tytoniowych, dbałość o higienę żywienia zwłaszcza w konte-

${ }^{82}$ CBOS, 7.09.2012.

83 Zob. Program projektu..., s. 15. 
kście diety - bark aktywności fizycznej, ale także ograniczona wiedza dotycząc przesłanek zachorowań.

Warunki pracy, ze szczególnym uwzględnieniem ekologii miejsca aktywności zawodowej, a zwłaszcza wykonywanie jej w tzw. profesjach o podwyższonym ryzyku zachorowalności.

Dodatkowo wskazać należy jako determinanty czynniki kulturowe czasami stanowiące barierę tj. wstyd przed wizytą u urologa. Kwestie społeczne dotyczące utraty pracy, dochodów, które mogą wpływać na brak stabilizacji ekonomicznej rodziny, co sprzyja także stosowaniu rozwiązań alternatywnych przedłużających fazę początkowego stadium diagnozowania, np. zażywanie leków przeciwbólowych, wreszcie brak wiary w skuteczność leczenia. Z tego względu za konieczne uznać należy podjęcie działań na rzecz podniesienia poziomu świadomości co do okoliczności sprzyjających zachorowaniom, podejmowanie działań profilaktycznych, za cenne uznać należy także wszelkie inicjatywy dotyczące edukacji prozdrowotnej w kontekście wczesnego wykrywania schorzenia.

Wydaje się, że w polityce bezpieczeństwa i dbałości o kondycję zdrowotną istotnym czynnikiem może być wprowadzenie obowiązkowych badań urologicznych dla mężczyzn powyżej 45 roku życia chociażby w określonym przedziale czasu, szczególnie w regionach o wysokim poziomie ryzyka zachorowalności, a zatem tam gdzie występują okoliczności sprzyjające ryzyku zachorowań. Za celowe także uznać należy, opracowanie systemu komunikacji między lekarzem specjalistą np. onkologiem czy urologiem a lekarzem rodzinnym, co znacznie ułatwiłoby wdrażanie systemu leczenia pacjenta.

Jak wcześniej podkreślano czynnikiem wpływającym na sukces podejmowanych działań profilaktycznych są także prowadzone kampanie informacyjne, za pośrednictwem dostępnych środków przekazu. Z uwagi na to, że stan zdrowia stanowi przedmiot zainteresowania osób bezpośrednio zainteresowanych, ale również osób najbliższych, przeto należy przygotować kampanię nie tylko uświadamiająca mężczyzn, ale również skierowaną do najbliższych, przede wszystkim partnerów życiowych.

Za niezbędne uznać należy zwiększenie zaangażowania służb medycznych $\mathrm{w}$ proces podnoszenia świadomości wśród pacjentów co do ryzyka zachorowań. Za ważne uznać należy przeprowadzenie profilaktycznej rozmowy z pacjentem, dotyczącej ewentualnego ryzyka zachorowalności, jak również wpływu wczesnej diagnostyki jako ważnego elementu zapobiegającego zachorowaniom. Szczególna rola przypada tutaj lekarzom POZ i medycyny pacy. Pozostając w bliskim kontakcie 
z pacjentem mogą mieć wpływ, na podstawie dokonywanej analizy wyników badań, na dalsze działania podejmowane przez pacjentów w trosce o zdrowie ${ }^{84}$.

Niezbędną jest także współpraca $\mathrm{z}$ organami administracji samorządowej, bowiem to właśnie na najniższym poziomie działalności administracyjnej państwa najszybciej można dokonać oceny stanu zagrożeń zdrowotnych, by w oparciu o posiadaną wiedzę podejmować decyzje mające na celu przeciwdziałanie zagrożeniom. Za szczególnie ważne uznać należy bezpośredni kontakt $\mathrm{z}$ beneficjentami, a co za tym idzie monitorowanie skali ich potrzeb i odpowiednio dobranego systemu narzędzi niezbędnych do podejmowania działań profilaktycznych, edukacyjnych. Przeprowadzenie akcji ogólnokrajowej czy lokalnej, udział lokalnych liderów, zaangażowanie pracodawców, może istotnie wpływać na poziom świadomości mężczyzn co do ryzyka zachorowań. Opracowanie skutecznej profilaktyki może istotnie wpłynąć na kondycję zdrowotną polskiego społeczeństwa, zważywszy na fakt, że jak wynika z poniżej zamieszczonych danych Polska zaliczana jest do społeczeństw starzejących się, a zatem dbałość o zdrowie osób w średnim wieku przyniesie wymierne korzyści w przyszłości, zwłaszcza na terenie obszarów, w których ryzyko zachorowań jest wyższe (por. rys. 5).

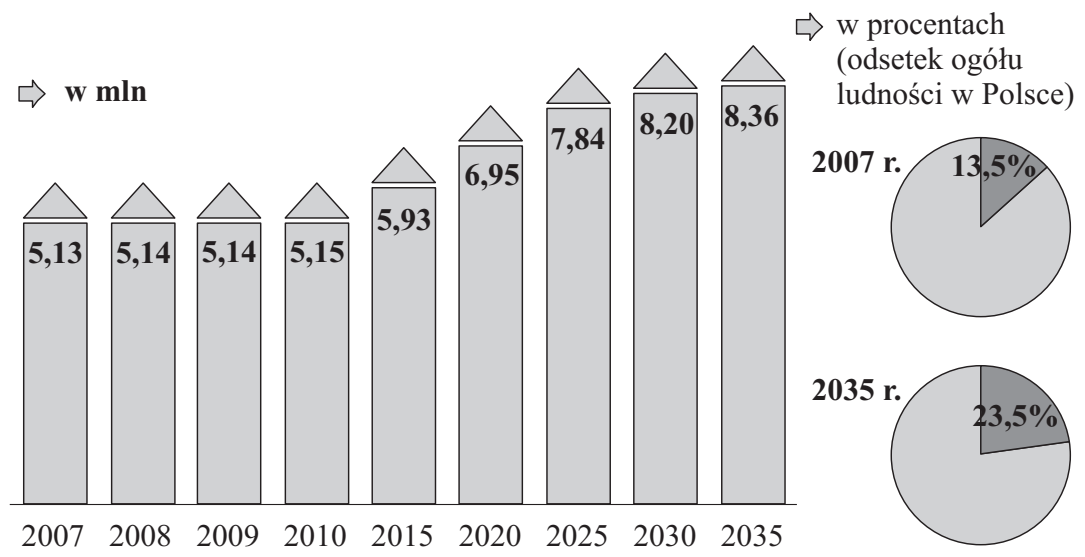

Rys. 5. Seniorzy w Polsce. Liczba osób powyżej 65. roku życia Źródlo: GUS, od 2015 roku prognozy; Infografika: PAP, M. Sitkiewicz wp.pl.

${ }^{84}$ Por. Wytyczne postępowania dla lekarzy POZ i lekarzy medycyny pracy w zakresie raka nerki, pęcherza moczowego i prostaty, Warszawa 2011. 
Synergia podejmowanych działań stanowi ważny czynnik wpływający na skuteczność powodzenia kolejno realizowanych programów profilaktycznych. Ich podstawowym założeniem często jest wzrost świadomości ryzyka zagrożeń oraz możliwości im przeciwdziałania. Perspektywiczne rozwiązania mają na celu przede wszystkim zapewnienie jak najlepszej jakości życia, jak również zrównoważenie poziomów bezpieczeństwa zdrowotnego.

\section{Protection of health as an element of public policy}

\section{Summary}

Public health is strictly related to health policy, since political decisions determine the selection of priorities and the distribution of assets. Health, perceived in this way, is protected by global activities, and not only by a given country or region. Health is a significant element among the tasks handled by public authorities. A consequence of these activities is ensuring medical care by means of developing the right apparatus and mechanisms of solutions allowing for common access to treatments offered. 
